\title{
Sequence Stratigraphy of Lower Carboniferous Rocks in Bakhshi Section, East-Central Iran
}

\author{
Soheil Erfani ${ }^{1 *}$, Mohammad Hossein Adabi ${ }^{2}$, Mahmood Reza Majidifard ${ }^{3}$, \\ Nader Kohansalghadimvand', Bibihaniyeh Emraninasab ${ }^{1}$
}

\author{
${ }^{1}$ Department of Geology, Islamic Azad University, North Tehran Branch, Tehran, Iran \\ ${ }^{2}$ Department of Earth Sciences, Shahid Beheshti University, Tehran, Iran \\ ${ }^{3}$ Research Institute for Earth Sciences, Geology Survey of Iran, Tehran, Iran \\ Email: ${ }^{\star S} \_$erfani $87 @$ yahoo.com
}

How to cite this paper: Erfani, S., Adabi, M.H., Majidifard, M.R., Kohansalghadimvand, N. and Emraninasab, B. (2017) Sequence Stratigraphy of Lower Carboniferous Rocks in Bakhshi Section, East-Central Iran. Open Journal of Geology, 7, 200-211.

https://doi.org/10.4236/ojg.2017.72014

Received: January 2, 2017

Accepted: February 24, 2017

Published: February 27, 2017

Copyright $\odot 2017$ by authors and Scientific Research Publishing Inc. This work is licensed under the Creative Commons Attribution International License (CC BY 4.0).

http://creativecommons.org/licenses/by/4.0/

\begin{abstract}
The deposits of Lower Carboniferous rocks in Kalmard Block are characterized by Gachal informal formation, showing various properties in different outcrops. These deposits (in Gachal formation) are composed chiefly of carbonate, evaporite and siliciclastic rocks. This formation commonly hosts $190 \mathrm{~m}$ sandstone, limestone, dolomitic limestone and dolomite as well as a small amount of shale and marl in the Bakhshi section. It unconformably underlies Devonian deposits (Rahdar formation) while lateritic soils of lower Permian (Chili formation) are depicted overlying an erosional unconformity above this formation. The mixed carbonate-evaporite-siliciclastic sequence of Gachal formation is made up of three third-order depositional sequences, separated from each other by Type 1 sequence boundary (SB1). Siliciclastic and evaporite deposits include LST system tract, whereas carbonate microfacies involve TST and HST system tracts, separated from each other by MFS. The depositional sequences identified in Gachal formation point to the Lower Carboniferous age, conforming to upper Kaskaskia supersequence. The upper erosional boundary between Gachal and Chili formations complies with the global-scale sea level fall.
\end{abstract}

\section{Keywords}

Lower Carboniferous, Kalmard Block, Gachal Formation, Sequence Stratigraphy

\section{Introduction}

Central Iran zone, shaped like a triangle and as one of the major, largest and most complex geological units in Iran, is situated in the center of Iran. Structural model 
of this area consists of blocks separated by deep faults, thereby exhibiting distinct properties. Kalmard Block, showing a northeastern trend, is placed between Kalmard faults in the east and those of Naein in the west [1].

\section{Bakhshi Section}

This section is located in southwestern Kalmard Caravansary (at 1:250,000 scale) [2] and northeast of Robate-khan village in Kalmard zone (at 1:100,000 scale) [3]. It is formed by geographical coordinates of $33^{\circ} 29^{\prime \prime} 59^{\prime} \mathrm{N}$ and $56^{\circ} 13^{\prime \prime} 56^{\prime} \mathrm{E}$, and is located about 95 kilometers from Tabas-Ardekanold main road, accessible by a one-kilometer-dirt road (Figures 1-3).

\section{Methodology}

To determine the sequences in this section, the geological maps of Tabas (at 1:250,000 scale) [2] and Robate-khan (at 1:100,000 scale) [3] are employed, and then the required data are collected though examining literature including textbooks, papers, reports, etc. Regarding field observations, the lithological character-

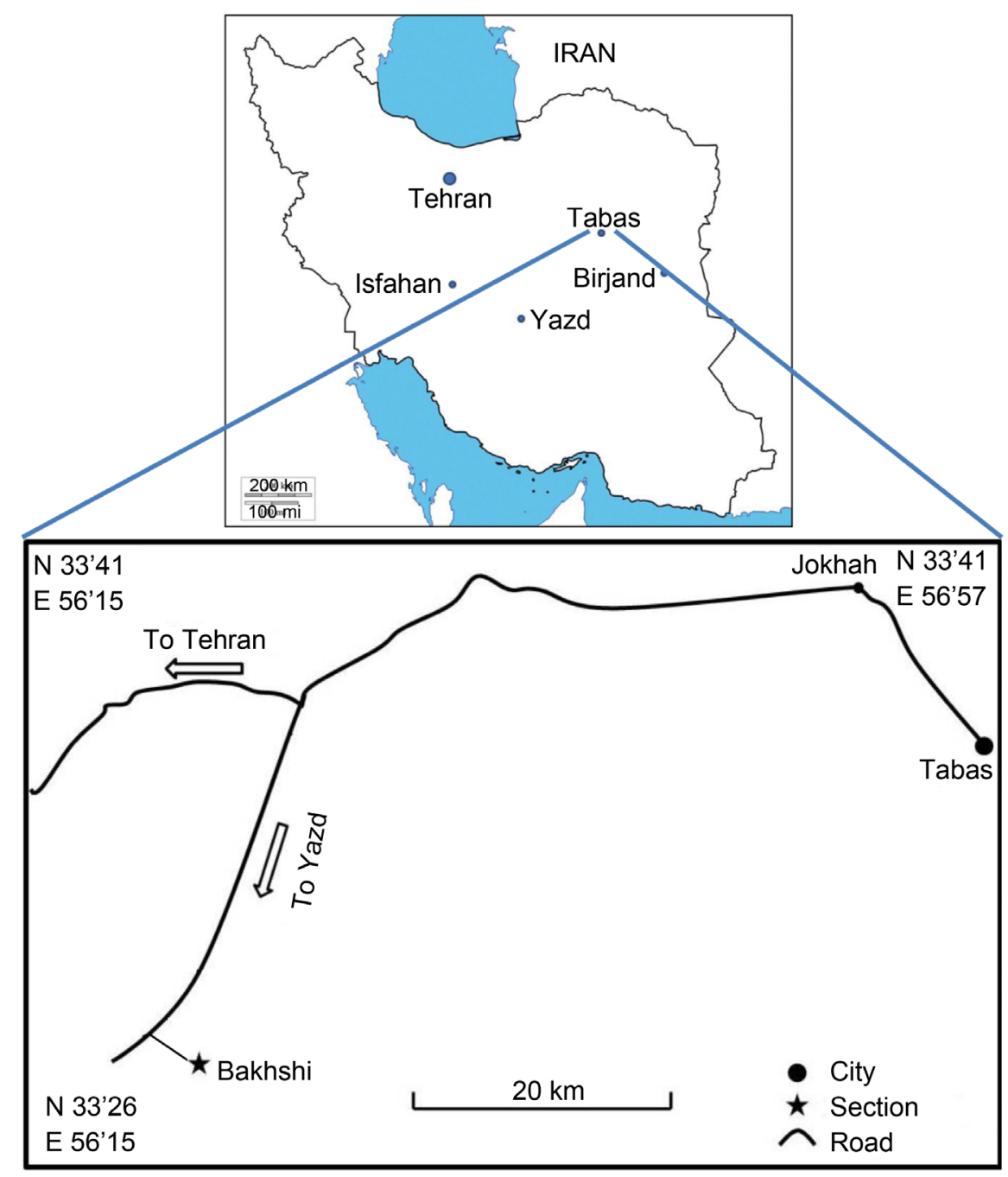

Figure 1. Geographical setting and access way to Gachal formation in Bakhshi section. 


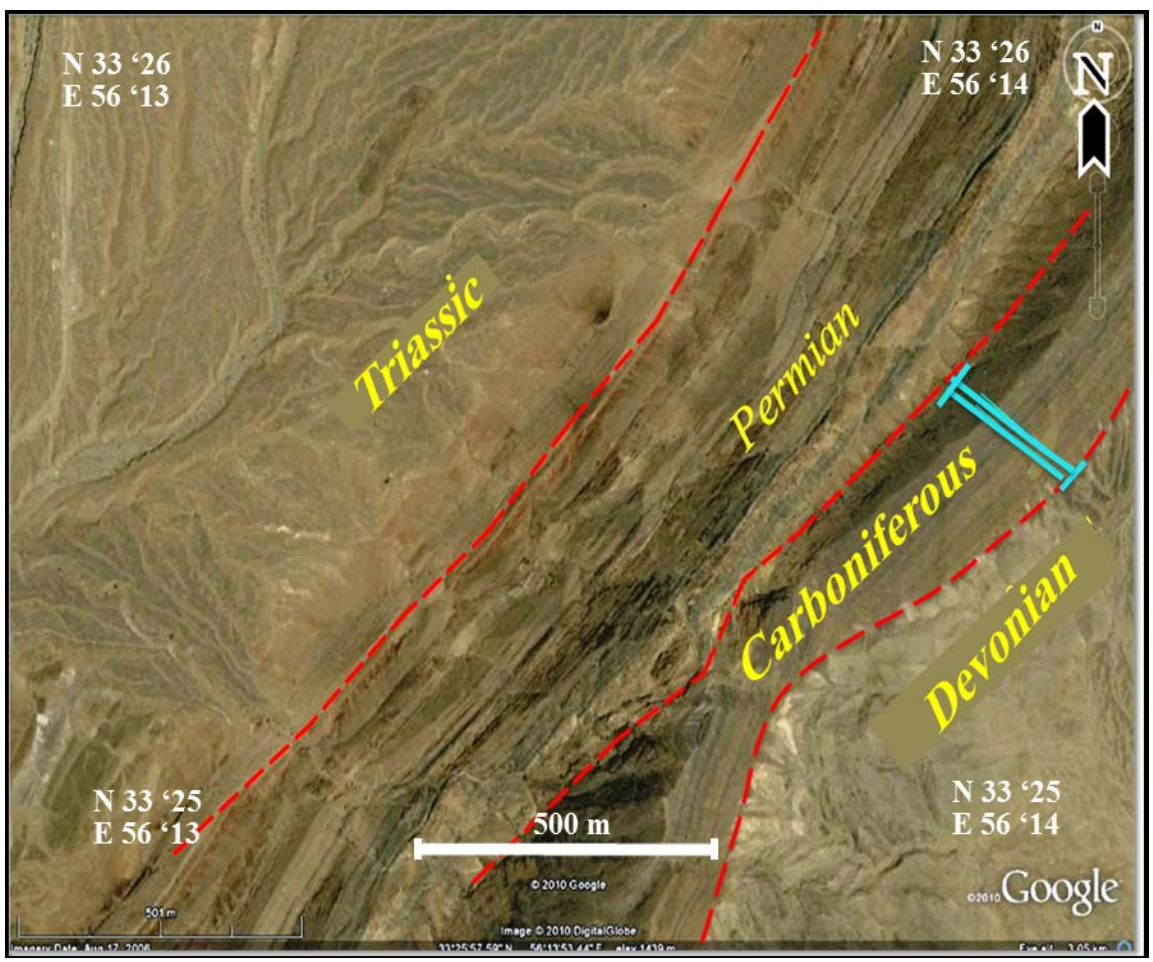

Figure 2. Satellite image of Gachal formation in Bakhshi section, separation of sediments age based on Tabas map (at 1:250,000 scale) (Aghanabati, 1977).

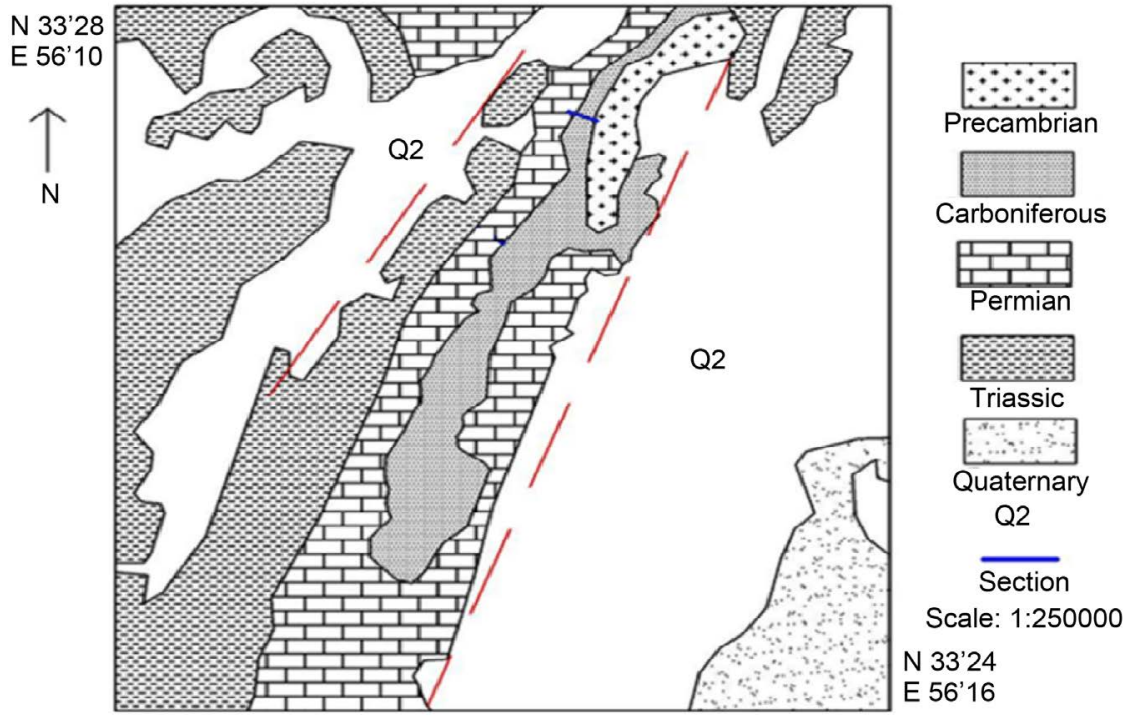

Figure 3. Geological map of Gachal formation in Bakhshi section (Aghanabati, 1977).

ristics of the sequence including gradation, various depositional structures, various fossils and parasequences stacking pattern are recorded, and major stratigraphic surfaces such as maximum flood surface (MFS), sequence boundaries (SB) and transgressive surface (TS) are identified. According to laboratory investigations, moreover, microscopic thin sections are used to reveal the characteristics of microscopic facies (namely, grain size and other textual features), diagenetic characteristics and microfossils. Field and microscopic evidence is also used to 
discuss the sequence stratigraphy of the studied sequence. Next, parasequences stacking pattern, unconformity surfaces, system tracts and the status of the studied sequence stratigraphy among the global sequences are also determined. Adopting Dickson's 1965 method [4], Alizarin-red S is used to stain the thin sections to identify the type of carbonate minerals (distinguishing calcite from dolomite). Having studied various methods in sequence stratigraphy studies, the depositional sequence model devised by Posamentier (1988) is used [5]. Regarding this model, "sequence stratigraphy" involves the study of rock relationships within the chronostratigraphic framework of a sequence, which in turn is acyclic succession of rocks composed of genetically related units of strata [5]. Finally, all information and data are combined, interpreted and explained.

\section{Stratigraphy}

Lower Carboniferous rocks deposit (Tournaisian-Visean-Serpukhovian stages), composed of limestone, dolomitic limestone, dolomite and gypsum as well as a small amount of mudstone in its upper parts is recognized by Gachal informal formation in Kalmard Block [1]. One of the most comprehensive outcrops of Gachal formation is located in Bakhshi section, in which deposits of Gachal formation rocks have StrikeE 25 N, Dip 44 NW and $58.6 \mathrm{~m}$ thickness. The lithology of Gachal formation in Bakhshi section is composed chiefly of mudstone and limestone, dolomitic limestone, dolomite and a small amount of shale, marl and gypsum. Based on morphologic and lithologic characteristics, this section can be divided into seven units including: a sequence of dolomitic sandstone and thinto-thick bedded, reddish yellow sandstone along with thickening-upward cycles with $35 \mathrm{~m}$ in thickness (Unit 1), unconformably overlying Devonian carbonate deposits (Rahdar formation), a sequence of limestone and horizontally laminated, medium-to-thick bedded, gray to cream dolomitic limestone with $45 \mathrm{~m}$ in thickness (Unit 2), massive-to-thin bedded, brown sandstone along with thinning-upward cycles up to $50 \mathrm{~m}$ in thickness (Unit 3), a sequence of shale, siltstone, marl and thin bedded, yellowish green dolomite with thickness of $21 \mathrm{~m}$ (Unit 4), a sequence of 15-meter-thick, massive-to-thick bedded, dark gray limestones with shear modes observed in their lower parts (Unit 5), horizontally stratified, highly thick bedded, reddish sandstone with a thickness of $12 \mathrm{~m}$ (Unit 6) and thick-tothin bedded, gray limestone with $12 \mathrm{~m}$ in thickness (Unit 7). The unit unconformably underlies thick-to-thin bedded, red, lateritic sandstone of Chili formation (Lower Permian) (Figure 4).

\section{Sequence Stratigraphy of Gachal Formation in Bakhshi Section}

Sequence stratigraphy is a method of classifying and interpreting sedimentary rocks and fossils in terms of variations in the environments [6]. The variation in the weather and sea level can be detected through careful analysis of sequence stratigraphy [7]. According to the investigations into the various sections of Gachal formation in Bakhshi section, Kalmard Block, three third-order, siliciclastic- 


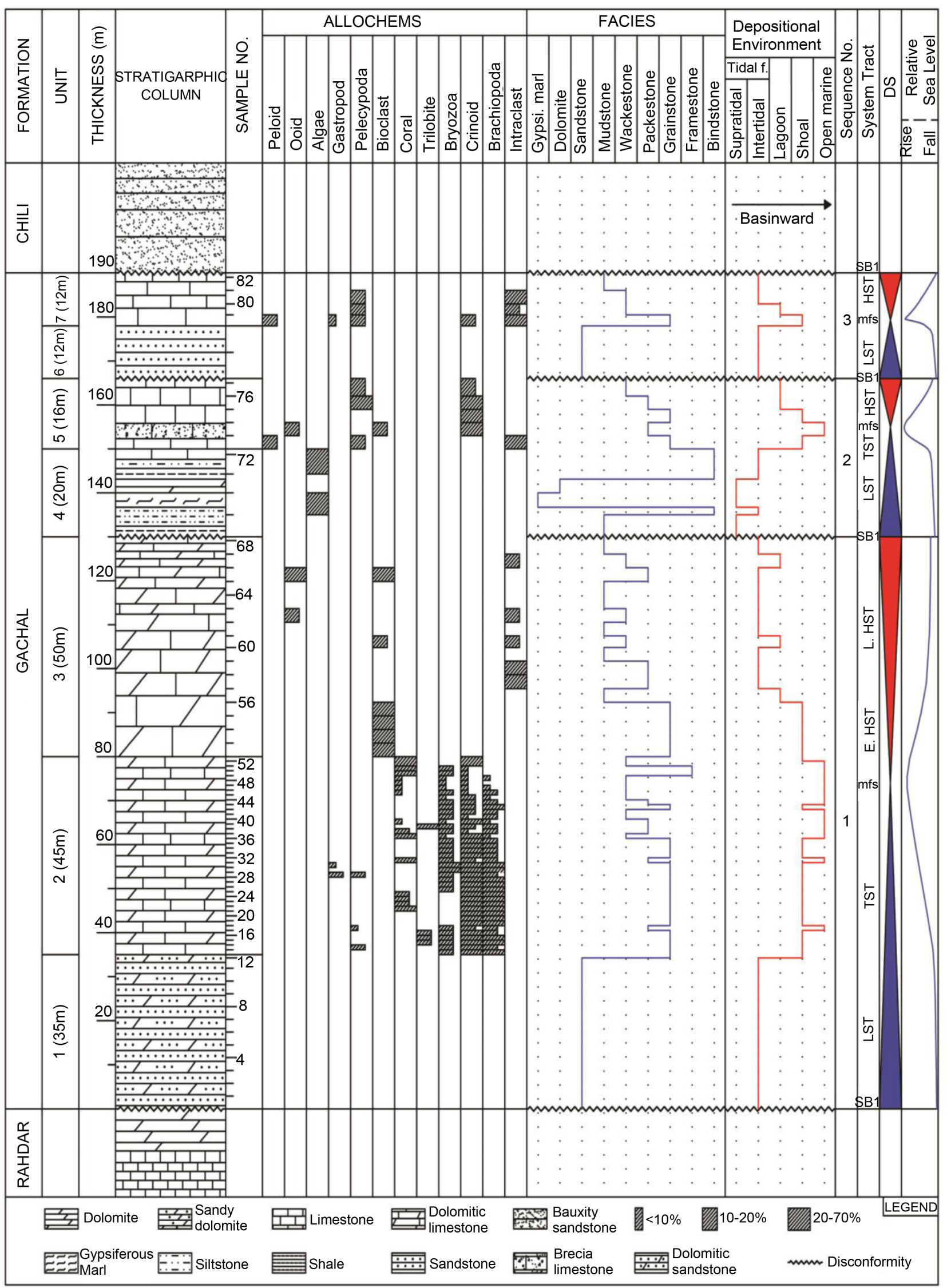

Figure 4. Frequency column of depositional sequences of Gachal formation in Bakhshi section. 
evaporite-carbonate depositional sequences, belonging to Lower Carboniferous are identified. All and all, the source of sediment supply is the first factor causing distinction between carbonate and siliciclastic systems [8]. Generally speaking, these sequences exhibit the following properties.

\subsection{First Depositional Sequence}

As a siliciclastic-carbonate sequence, this $130 \mathrm{~m}$ thick depositional sequence is the lowest sequence, both overlain and underlain by type 1 sequence boundary. In this sequence, LST system tract (Low Stand System Tract) unconformably overlies Devonian carbonate deposits by extending microfacies of supratidal subenvironment. LST is composed of silica clastic facies of tidal flat environment (intertidal subenvironment), containing quartzarenite petrofacies with progradational staking pattern and carbon atemicro facies of tidal flat environment (supratidal subenvironment), containing fenestral bioclastwackstone. This system tract is mostly observed in the desert as a sequence of dolomite and thickto-medium bedded, reddish yellow sandstone with $35 \mathrm{~m}$ in thickness (Figure 4). Progradationally overlying the LST system tract, the TST system tract (Transgressive System Tract) covered by thin-bedded limestones is characterized by shoal microfacies (dolomitized bioclastgrainstone). TST system tract, showing deepening trend with retrogradational stacking pattern, consists of carbonate parasequences of shoal environment (dolomitizes bioclastgrainstone, dolomitized bryozoan trilobite crinoid grainstone and brachiopod crinoid grainstone) and open marine environment (dolomitized crinoid bryozoan packstone, dolomitized crinoid coral packstone and bioclastwackstone). This system tract is observed as a sequence of limestone and horizontally laminated, gray to cream, medium-tothin bedded dolomitic limestone with a thickness of $42 \mathrm{~m}$. It is progradationally followed by maximum flooding surface (MFS), identified by bioclastwackstone microfacies, containing open marine crinoids and brachiopods. In this situation, the area develops between maximum sea level and maximum uplift rate of relative sea level. This surface, immediately preceded by TST system tract, is characterized by horizontally stratified, thin-bedded gray limestone. HST system tract (High stand System Tract), exhibiting a shallowing trend with progradational stacking pattern, contains open marine, shoal, lagoonal and tidal flat (supertidal) microfacies. HST system tract is divided into Early HST and Late HST. Early HST includes open marine microfacies (bioclastwackstone) and shoal microfacies (dolomitized framestone and dolomitized bioclastgrainstone). In desert, it is observable in terms of horizontally stratified, massive-to-thick, brown dolomitic limestone with $35 \mathrm{~m}$ thick. However, Late HST contains lagoonmicrofacies (sand mudstone, pellet intraclast pelecypoda wackstone) and tidal flat microfacies (intertidal subenvironment) (fenestral intraclast ooid packstone, and fenestral mudstone). In desert, it can be found as horizontally stratified, medium-to-thin bedded, brown dolomitic limestone with a thickness of $18 \mathrm{~m}$. This sequence finally ends in SB1, characterized by gypsiferous mudstone microfacies of supratidal flat subenvironment (Figures 5-8). 


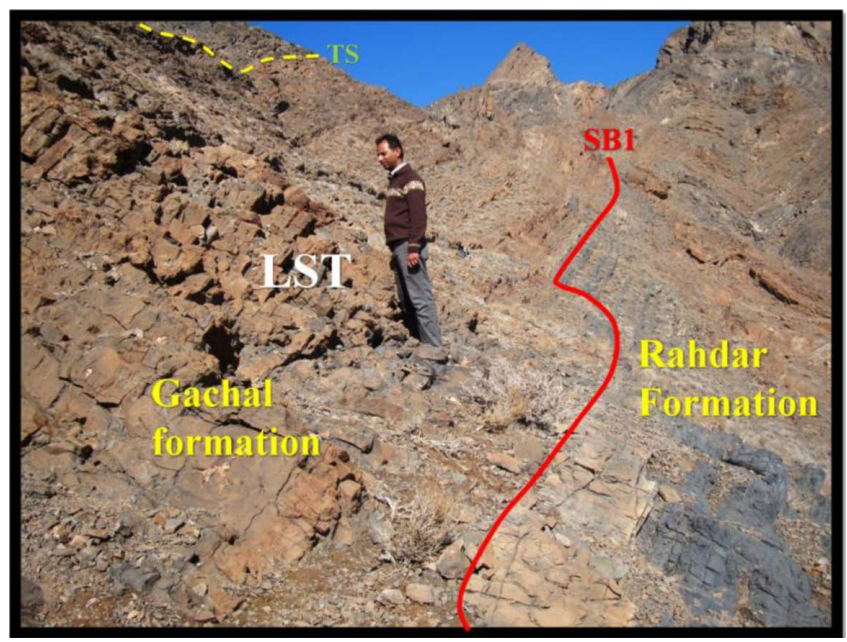

Figure 5. Image of the first depositional sequence of Gachal formation in Bakhshi section. Scale: standee; $1.63 \mathrm{~m}$ (northeasternward view).

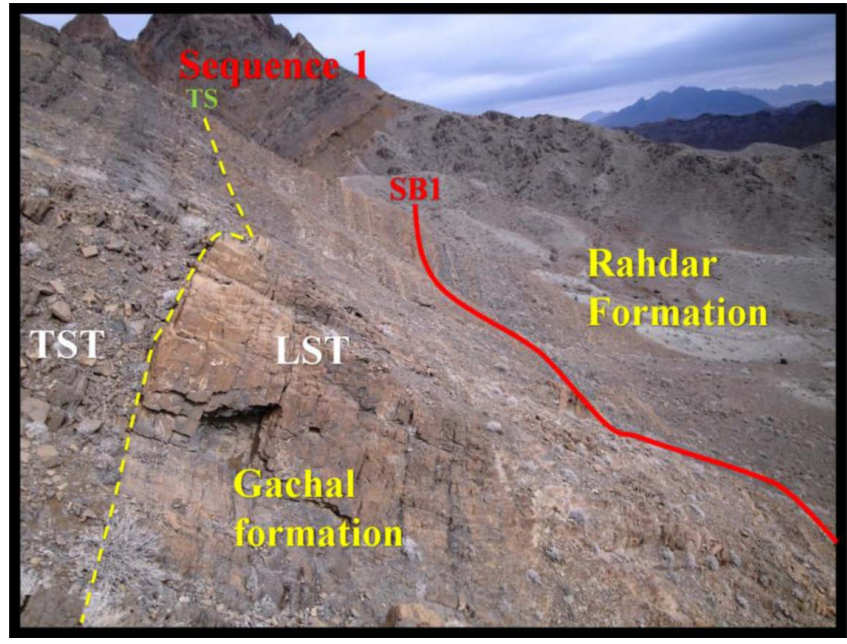

Figure 6. Image of the first depositional sequence of Gachal formation in Bakhshi section (northeasternward view).

\subsection{Second Depositional Sequence}

This $129 \mathrm{~m}$ thick depositional sequence overlies the first depositional sequence by type 1 sequence boundary. In this sequence, LST system tract immediately overlies SB1, and tidal flat microfacies are deposited due to the sea level fall. This system tracts includessupratidal subenvironment, which contains gypsiferous mudstone and intertidal subenvironment, that in turn consists of fenestral mudstone and dolomitized fenestralboundstonestromatolite. This depositional system tract can be found in the desert in terms of a sequence of marl, shale, siltstone and horizontally stratified, thin bedded, yellowish green dolomite with $21 \mathrm{~m}$ in thickness (Figure 4). TS has progradationally overlain LST system tract and is characterized by massive limestone and shoal microfacies (bioclastooidgrainstone). TST system tract, showing deepening trend with retrogradational stacking pattern, consists of carbonate parasequences of open marine environment (crinoid packstone) and 


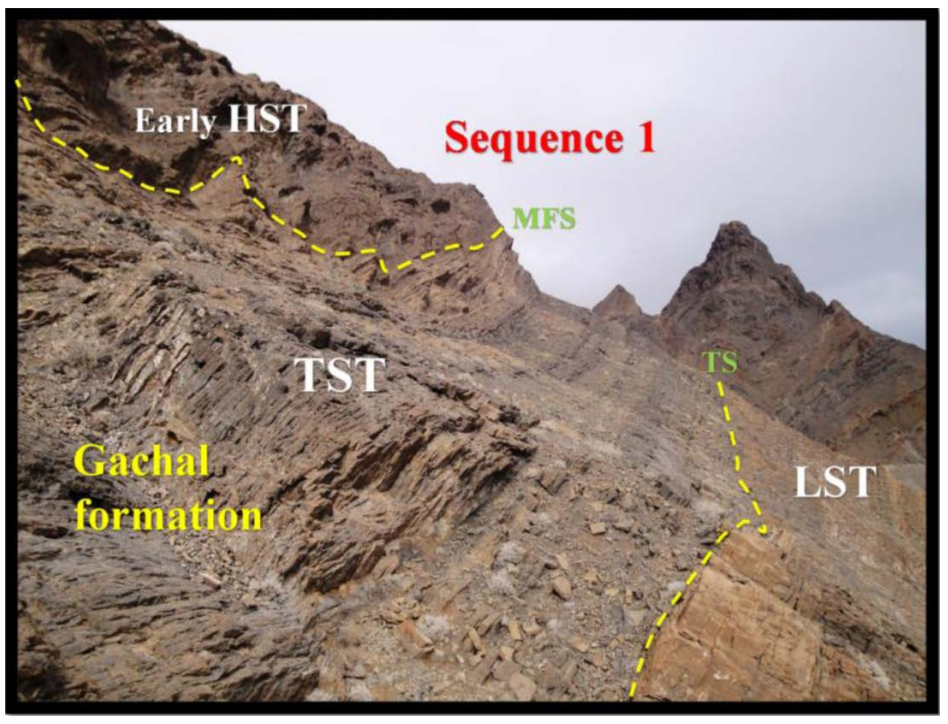

Figure 7. Image of the first depositional sequence of Gachal formation in Bakhshi section (northeasternward view).

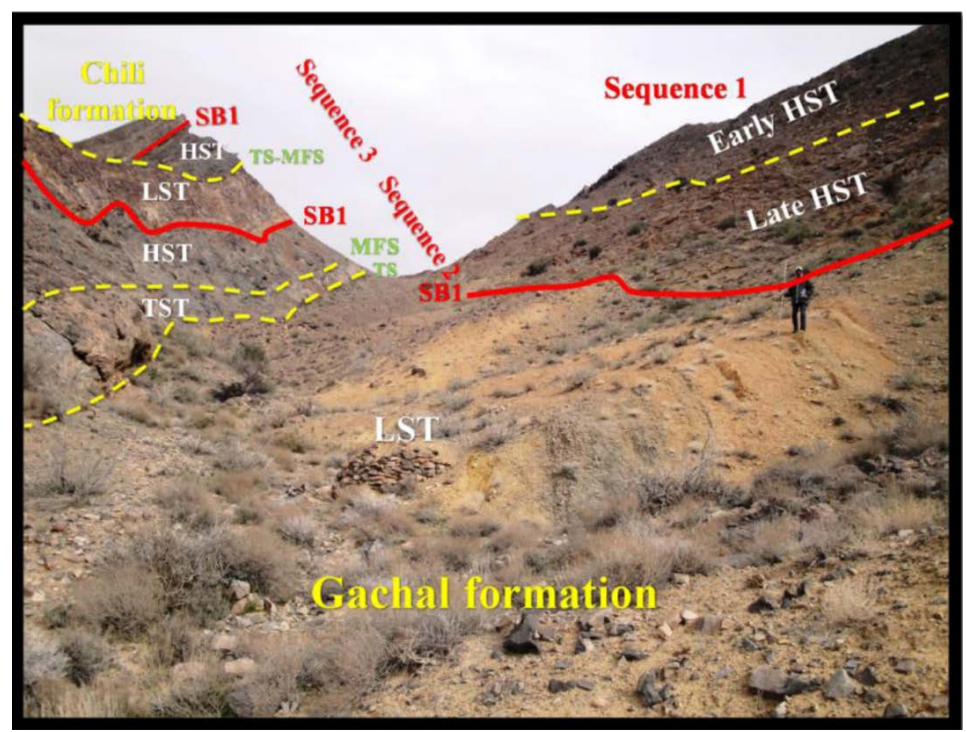

Figure 8. Image of the first, second and third depositional sequences of Gachal formation in Bakhshi section, scale: standee, $1.70 \mathrm{~m}$ (northeasternward view).

shoal environment (bioclastooidgrainstone). TST has $4 \mathrm{~m}$ thickness and is observed as a sequence of massive-to-thick bedded, gray limestone. MFS, following TS, is characterized by crinoid packstone microfacies of open marine environment and related to horizontally stratified, thick bedded, gray limestone in desert. HST system tract, showing a progradational stacking pattern, is characterized by thick bedded, gray limestone with thickness of $11 \mathrm{~m}$. This system tract, exhibiting a deepening trend, is covered by shoal microfacies (crinoid grainstone) and lagoon microfacies (crinoid pelecypodawackstone/ packstone). This sequence is overlain by SB1, identified by quartzarenitesiliciclasticfacies of intertidal subenvironment (Figure 8). 


\subsection{Third Depositional Sequence}

This depositional sequence is $24 \mathrm{~m}$ thick and covers the second depositional sequence by type 1 sequence boundary. In this sequence, LST system tract immediately overlies SB1, and siliciclasticfacies of tidal flat environment is laid due to the sea level fall. This system tract contains quartzarenitepetrofacies with progradational stacking pattern, which belongs to intertidal subenvironment. This depositional system tract can be found in the desert in terms of horizontally stratified, thick bedded, reddish sandstones with $12 \mathrm{~m}$ in thickness (Figure 4). Complying with MFS, TS has progradationally overlain LST system tract and is characterized by intrac lastbioclastgrainstone, while, in desert, can be found in horizontally stratified thick-bedded, grayish limestones.

HST system tract, showing deepening trend with progradational stacking pattern, is characterized by horizontally stratified, thick-to-medium bedded, grayish limestone with thickness of $12 \mathrm{~m}$ and consists of lagoon environment (pellet intraclast pelecypoda wackstone) and tidal flat environment (fenestral mudstone and fenestralbioclastwackstone). This sequence finally ends in SB1, containing eroded, thick-to-medium bedded, dark red lateritic sandstone. These sandstones are associated with Chili formation (lower Permian), unconformably overlying Gachal formation in Bakhshi section and recognizing the boundary between Gachal and Chili formations (Figure 8).

\section{Interpretation of the Depositional Sequence Identified in Gachal Formation in Bakhshi Section}

According to microscopic investigations, field observations and sequence stratigraphy, Gachal formation in Bakhshi section involves three third order depositional sequences and a lot of high frequency cycle. These sequences are equivalent to upper parts of subordinate large-scale Kaskaskia [9] (asterisk in Figure 9). The lower boundary of the first depositional sequence of Gachal formation in Bakhshi section is a Type 1 unconformity, overlying the Devonian carbonate deposits (Rahdar formation) and includes a sequence of dolomitic sandstone and thin-to-thick bedded yellowish red sandstone, arranged in thickening-upward cycles. These deposits are composed of siliciclastic-carbonate deposits, and its MFS is identified by bioclastwackstone microfacies, containing open marine crinoids and brachiopods. The second depositional sequence is made up of carbonate and a little evaporate parasequences. The relative sea level fall has triggered the formation of tidal flat deposition (supratidal subenvironment) at the beginning parts of this sequence. Its MFS is characterized by open marine crinoid packstone microfacies. The third depositional sequence is like the first one, that is to say it is composed of siliciclastic-carbonate deposits. This sequence contains a set of tidal flat parasequences (intertidal subenvironment) and shoal environments, and its MFS is recognized by intrac lastbioclastgrainstone, belonging to shoal environment. In Kalmard siliciclastic-carbonate-evaporite platform, the sedimentary basin reacts more apparently against sea-level fluctuation due to its shallowness. The sandstones at the beginning of the first and third sequences confirm this 


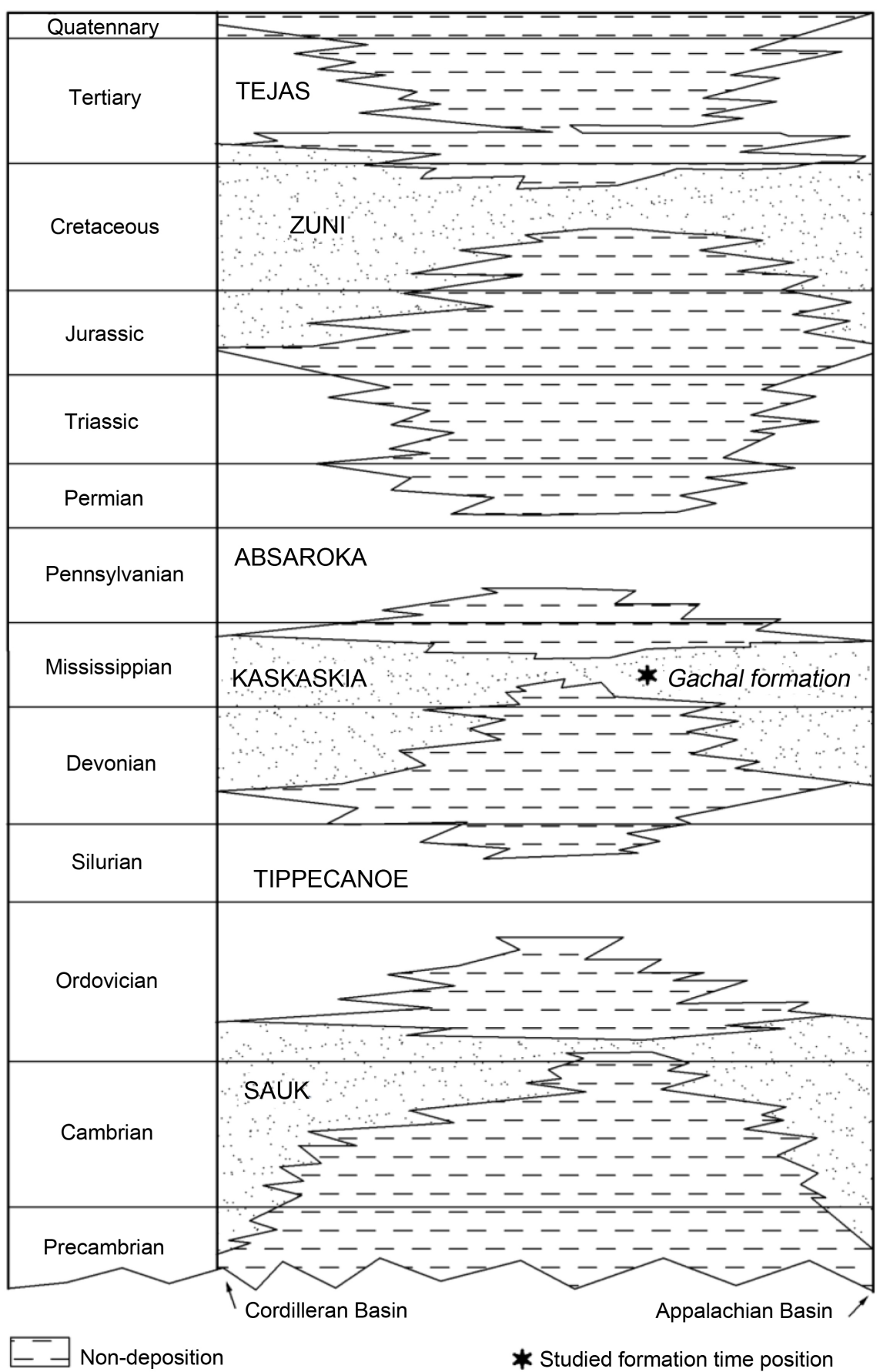

Figure 9. Gachal formation setting in Bakhshi section and global-scale subsequences are marked by asterisk (Sloss, 1963).

claim and point to the rapid change in the conditions. Therefore, one can claim that relative sea level fall leads to the formation of SB1 and thick sandstone horizons between the sequences of Gachal formation and Gachal and Chili boundary. One of the consequences of LST system tract in siliciclastic-carbonate systems is the extension of siliciclastic depositions. Once sea level is lower than the edge of the continental shelf, more siliciclastic materials flow into the environment [10]. 
Regarding the evidence, the sequence model of this formation suggests once the sea water moves forward; calcareous deposits of lagoon, shoal and open marine microfacies are deposited over the sandstone deposits of tidal flat environment. The rate of sea level fall exceeds the rate of tectonic subsidence in SB1, thereby causing the depositional environment to move out of water.

\section{Conclusions}

Having analyzed the facies, depositional environment and sequence stratigraphy of the deposits of Gachal formation in Bakhshi section, the researchers came up with the following results:

Deposits of Lower Carboniferous rocks (Tournaisian-Visean-Serpukhovian stages) in Kalmard Block are recognized with Gachal informal formation and composed chiefly of limestone, dolomitic limestone, dolomite and gypsumas well as a small amount of sandstone at its beginning and end. One of the most comprehensive outcrops of Gachal formation is located in Bakhshi section, which shows $190 \mathrm{~m}$ thickness in the sampling area. Regarding the carbonate compound of the rocks of this formation, along with siliciclastic and evaporite deposits, the rocks of Gachal formation are deposited near the supply source of siliciclastic deposits and in a hot and dry weather condition. According to the microscopic investigations, field observations and sequence stratigraphy, the carbonate-evaporite-siliciclastic sequence of Gachal formation is made up of three third-order depositional sequences and lots of high frequency cycles. These sequences are equivalent to upper parts of subordinate large-scale Kaskaskia. The lower boundary of the first depositional sequence of Gachal formation in Bakhshi section is a Type 1 unconformity, overlying the Devonian carbonate deposits (Rahdar formation) and includes a sequence of dolomitic sandstone and thin-to-thick bedded, yellowish red sandstone along with thickening-upward cycles. This depositional sequence is made up of carbonate-siliciclasticparase-quences, and its MFS is identified by bioclast wackstone microfacies, containing open marine crinoids and brachiopods. The second depositional sequences are composed of carbonate and evaporation parasequences, and its MFS is characterized by open marine crinoid packstone microfacies. The relative fall in sea level results in tidal flat deposits (supratidal subenvironment) at the entry of this sequence. The third depositional sequence is like the first one, that is, it is composed of siliciclastic-carbonate deposits. This sequence contains a set of tidal flats (intertidal subenvironment) to shoal parasequences, and its MFS is recognized by shoal intraclast bioclast grainstone microfacies. In this sequence, sea level fall is likely the result of global-scale glacial and local tectonic activities (subsidence of basin floor and vertical movement of the existing faults). It is noteworthy that the studied area shows no glacial activities like dropstone, Striation and Diamicitite, yet the global sequences are formed as a result of sea level fall on a global scale.

\section{References}

[1] Aghanabati, A. (2004) Geology of Iran. Geological Survey of Iran, Tehran, 606 p.

[2] Aghanabati, A. (1977) Etudgeologique de la region de Kalmard (W. Tabas). Geolo- 
gical Survey of Iran, No. 35, 51-63.

[3] Azhdari, A. (1999) Geological Map and Report of Robat-e-Khan, on Scale of 1:100000. Geological Survey of Iran, Tehran.

[4] Dickson, J. (1965) A Modified Staining Technique for Carbonate in Thin Section. Nature, 205, 587 p.

[5] Posamentier, H.M., Jervey, M.T. and Vail, P.R. (1988) Eustatic Controls on Clastics Deposition I-Conceptual Framework. In: Wilgus, C.K., Hasting, B.H., Posamentier, H., Van Wagoner, J.C., Ross, C.A. and Christopher, G., Eds., Sea Level Change an Integrated Approach, SEPM, Special Publication, Vol. 42, 109-124.

https://doi.org/10.2110/pec.88.01.0109

[6] Naish, T.R., Abbott, S.T. and Carter, R.M. (2013) Sequence Stratigraphy Reference Module in Earth Systems and Environmental Sciences. In: Elias, S.A., Ed., Encyclopedia of Quaternary Science, 2nd Edition, Elsevier, Amsterdam, 260-276.

[7] Patricio, R.D., Luis, A.B., Carlos, O.L. and Gabriela, A.C. (2009) Latest Carboniferous-Earliest Permian Transgressive Deposits in the Paganzo Basin of Western Argantina: Lithofacies and Sequence Stratigraphy of a Coastal Plain to Bay Succession. Journal of South American Earth Sciences, 28, 40-53. https://doi.org/10.1016/j.jsames.2008.10.003

[8] Schlager, W. (2005) Carbonate Sedimentology and Sequence Stratigraphy. SEPM Concepts in Sedimentology and Paleontology, 8, $200 \mathrm{p}$.

https://doi.org/10.2110/csp.05.08

[9] Sloss, L.L. (1963) Sequence in Cratonic Interior of North America. Geological Society of America Bulletin, 74, 93-114. https://doi.org/10.1130/0016-7606(1963)74[93:SITCIO]2.0.CO;2

[10] Alonso-Zarza, A.M. and Tanner, L.H. (2010) Carbonates in Continental Settings: Facies, Environments and Processes. Developments in Sedimentology, 61, 225-267.

Submit or recommend next manuscript to SCIRP and we will provide best service for you:

Accepting pre-submission inquiries through Email, Facebook, LinkedIn, Twitter, etc. A wide selection of journals (inclusive of 9 subjects, more than 200 journals)

Providing 24-hour high-quality service

User-friendly online submission system

Fair and swift peer-review system

Efficient typesetting and proofreading procedure

Display of the result of downloads and visits, as well as the number of cited articles

Maximum dissemination of your research work

Submit your manuscript at: http://papersubmission.scirp.org/

Or contactojg@scirp.org 